\title{
PROGRAM DESA WISATA AMAN DAN SEHAT: EDUKASI PENOLONG PERTAMA WISATA PULAU
}

Uti Rusdian Hidayat ${ }^{1^{*}}$, Nurpratiwi ${ }^{2}$, Debby Hatmalyakin ${ }^{3}$, Fauzan Alfikrie ${ }^{4}$, Ali Akbar $^{5}$, Mimi Amaludin ${ }^{6}$ Verren Kerren Tumundo ${ }^{7}$

1-7 STIKes Yarsi Pontianak

Email Korespondensi: utirhidayat@gmail.com

Disubmit: 15 November 2021 Diterima: 23 Desember $2021 \quad$ Diterbitkan: 02 Januari 2022 DOI: https://doi.org/10.33024/jkpm.v1i1.5493

\begin{abstract}
ABSTRAK
Kegawatandarutan bisa terjadi dimana saja terutama wisata pulau. Tujuan pengabdian kepada masyarakat untuk meningkatkan pengetahuan pertolongan pertama masyarakat wisata pulau. Metode pelaksanaan pengabdian kepada masyarakat adalah penyuluhan tentang pertolongan pertama wisata pulau kepada masyarakat Desa Lemukutan Kecamatan Sungai Raya Kepulauan. Hasil pengabdian kepada masyarakat didapatkan data terjadi peningkatan pengetahuan masyarakat sebelum dan setelah penyuluhan kesehatan tentang pertolongan pertama wisata pulau. Peningkatan pengetahuan masyarakat tentang pertolongan pertama menjadi upaya penanganan kegawatdaruratan di Pulau Lemukutan.
\end{abstract}

Kata Kunci: Pertolongan pertama, Pengetahuan, Edukasi

\begin{abstract}
Emergency condition can occur anywhere, especially island tourism. The purpose of community service was increased the knowledge of first aid for island tourism communities. The method of implementing community service is counselling about island tourism first aid to the people of Lemukutan Island, Sungai Raya Islands District. The results of community service showed that there was an increase in community knowledge before and after health counselling about island tourism first aid. Increasing public knowledge about first aid is an effort to handle emergencies on Lemukutan Island.
\end{abstract}

Keywords: First Aid, Knowledge, Education 


\section{PENDAHULUAN}

Out-of-Hospital Cardiac Arrest atau yang dikenal dengan henti jantung di luar rumah sakit merupakan kondisi yang seringkali mengancam hidup seseorang. Di beberapa negara kejadian henti jantung di luar rumah sakit mengalami peningkatan. American Heart Association pada tahun 2018 menjelaskan disebutkan bahwa insiden OHCA di Amerika mencapai 356.461 orang. Dari total jumlah tersebut, hanya $\pm 40 \%$ tindakan Resusitasi Jantung Paru yang dilakukan oleh orang - orang yang ada di sekitar korban. Angka keberlangsungan hidup korban yang memperoleh tindakan RJP dilokasi kejadian mencapai 9,5\% (Benjamin et al., 2018). Adapun keberlangsungan hidup korban dipengaruhi oleh salah satu factor seperti kecepatan tenaga kesehatan ke lokasi kejadian (Holmén et al., 2020). Namun, pada kenyataannya, petugas kesehatan tidak bisa segera mendatangi lokasi kejadian dikarenakan berbagai macam factor seperti jarak serta letak geografis. Oleh karena itu, masyarakatlah yang menjadi orang pertama dalam membantu korban di tempat (Goto, Funada, \& Goto, 2018). Kondisi ini mendeskripsikan bahwa masyarakat yang ada di sekitar korban memiliki peranan penting dalam meningkatkan keberlangsungan hidup pasien henti jantung.

Keberadaan serta jumlah masyarakat yang memberikan pertolongan RJP ketika menemui korban henti jantung secara mendadak masih tergolong rendah. Di Indonesia, kejadian henti jantung mencapai 10/10.000 penduduk yang <35 tahun dan setiap tahunnya berjumlah 300.000-350.000 kejadian henti jantung (IHA, 2015). Di Indonesia, sudah memiliki upaya dalam penanganan henti jantung berupa pembentukan Public Safety Center 119. PSC 119 didirikan dengan tujuan sebagai pusat pelayanan dalam menjamin kebutuhan masyarakat dalam hal-hal yang berhubungan dengan kegawatdaruratan. Masyarakat yang mengetahui dan mengalami kegawatdaruratan medis dapat melaporkan atau meminta bantuan melalui Call Center 119. Namun, pada kenyataannya PSC 119 belum berjalan dengan efektif (Budi, 2020). Banyak kendala-kendala yang muncul dalam proses pelaksanaannya seperti masih adanya kabupaten/kota yang belum terintegrasi dengan PSC 119 serta masih kurangnya sosialisasi kepada masyarakat tentang fungsi dari PSC 119 (Nurulita \& Darnoto, 2017). Kondisi inilah yang menjadi hambatan masyarakat dalam melakukan pertolongan pertama henti jantung.

Beberapa hambatan yang menyebabkan rendahnya jumlah masyarakat yang aktif memberikan pertolongan pertama ketika menemui korban henti jantung secara mendadak berupa kemampuan intelektual dan kepedulian dari masyarakat yang masih rendah untuk melakukan RJP (Krammel et al., 2020). Studi pendahuluan yang dilakukan peneliti menemukan bahwa masih banyak masyarakat kota Pontianak belum mengetahui cara mengenali, memanggil bantuan dan memberikan pertolongan pertama pada henti jantung. masyarakat juga tidak memiliki kepercayaan diri dalam menangani pasien henti jantung. Kondisi ini tentunya akan berdampak pada tingkat keberlangsungan hidup pasien dengan henti jantung.

Dalam rangka untuk meningkatkan jumlah dan keberadaan masyarakat yang mampu memberikan tindakan RJP ketika menemui korban henti jantung secara mendadak, American Hearth Ascociation telah mengembangkan program untuk memberikan pelatihan RJP pada komunitas. Pelatihan ini dilaksanakan untuk meningkatkan kesadaran masyarakat akan pentingnya peran masyarakat dalam penanganan pasien henti jantung(Kleinman et al., 
2015). Salah satu strategi pelatihan yang bisa digunakan untuk meningkatkan pengetahuan berupa Mnemonic method.

Mnemonic method merupakan salah satu strategi yang digunakan untuk mengoptimalkan kinerja ingatan dengan mengasosiasikan kata-kata gagasan atau ide dengan gambaran (Purnamasari, 2018). Fokus utama Mnemonic method yang berupa imajinasi dan asosiasi dapat mampu meningkatkan koordinasi antara otak kiri dan otak kanan dalam satu aktivitas belajar (Bakken, 2017). Pendekatan inilah yang digunakan peneliti untuk meningkatkan efektivitas pembelajaran pertolongan pertama henti jantung dengan Model "SELAMAT".

Model "SELAMAT" yang digunakan dalam pembelajaran pertolongan pertama henti jantung memiliki makna tersendiri disetiap hurufnya. Kata " $\mathrm{S}$ " menjelaskan selalu utamakan keamanan, "E" evaluasi kesadaran korban, "L" lihat sekitar dan minta bantuan, "A" amati apakah korban bernapas, "M" melakukan kompresi dada, "A" amati respon korban, "T" tunggu bantuan datang dan cek korban setiap 2 menit.

Berdasarkan permasalahan di atas, maka peneliti akan melakukan penelitian yang berjudul "Efektifitas Pelatihan Pertolongan Pertama Henti Jantung Dengan Model SELAMAT Terhadap Pengetahuan dan Keterampilan Masyarakat Kota Pontianak Tahun 2021".

\section{MASALAH}

Pemerintah yang menjadi penanggung jawab pengelolaan suatu tempat wisata perlu mengedepankan tujuan penjagaan keselamatan dan kesehatan pengunjung maupun masyarakat setempat. Hal ini dapat dilakukan dengan menyediakan sumber daya tim penyelamat dan tim kesehatan beserta fasilitasnya. Faktanya sumber daya dan fasilitas dalam pertolongan pertama belum memadai. Dengan demikian, kecelakaan yang beresiko menyebabkan kondisi kegawatdaruratan hingga mengancam keselamatan dengan berbagai faktor resiko atau penyebabnya tidak bisa ditebak kapan, pada siapa dan dimana akan terjadi. Faktanya, petugas penyelamat dan petugas kesehatan tidak selalu bisa tiba dilokasi dan memberikan pertolongan secara cepat.

Penguatan kapasitas masyarakat sebagai penyelamat dan penolong pertama merupakan hal yang penting mengingat ancaman kesehatan dan keselamatan nyawa di fase akut bisa terjadi dalam waktu yang singkat sehingga memerlukan respon pertolongan pertama yang cepat dan tepat oleh orang yang berada atau dekat dengan lokasi korban.

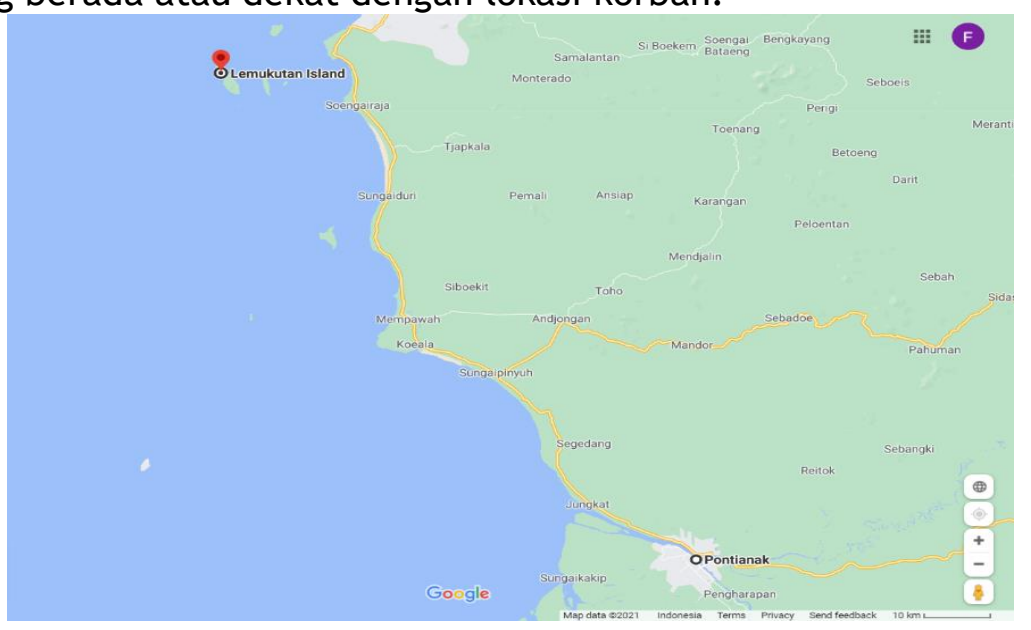

Gambar 1. Peta lokasi dan jarak Pontianak ke mitra Pulau Lemukutan 


\section{METODE}

a. Tahap Persiapan

Peserta pada pelatihan ini terdiri dari warga Desa Lemukutan yang berjumlah 30 orang. Sarana prasarana Kegiatan ini akan dilaksanakan di Desa Lemukutan Kabupaten Bengkayang Kalimantan Barat. Adapun perlengkapan yang di butuhkan diantaranya yaitu, fasilitas persentasi berupa laptop, LCD dan speaker serta fasilitas simulasi berupa Phantom BHD, serta Trauma Kit.

b. Tahap Pelaksanaan

Pelaksanaan pelatihan dan edukasi pertolongan pertama wisata pulau dilakukan pada tanggal 1 September 2021 pada pukul 10.30 sampai dengan 12.00 WIB. Metode yang digunakan berupa ceramah dan demonstrasi penolong pertama pada masyarakat pulau lemukutan. Sebelum diberikan pelatihan dan edukasi, masyarakat diukur tingkat pengetahuan dan keterampilan penolong pertama. Peserta diminta untuk mencoba satu persatu keterampilan sebagai penolong pertama. Hasilnya didokumentasikan dan ditambah pada formulir pengukuran. Selanjutnya diberikan edukasi dan demonstrasi sebagai penolong pertama. Peserta kembali diukur menggunakan formulir yang sama untuk tingkat pengetahuan dan kemampuan sebagai penolong pertama.

c. Evaluasi

Evaluasi kegiatan pelatihan dan edukasi berjalan dengan lancar yang diikuti seluruh peserta berjumlah 30 orang.

\section{HASIL DAN PEMBAHASAN}

Pelaksanaan pengabdian kepada masyarakat dalam kegiatan pelatihan dan edukasi penolong pertama diikuti oleh 30 peserta. Hasil pengabdian kepada masyarakat dijelaskan pada tabel 1.

Tabel 1. Distrbusi Frekuensi Pengetahuan Peserta Sebelum dan Setalah pelatihan dan edukasi penolong pertama

\begin{tabular}{cllll}
\hline \multirow{2}{*}{ Kategori } & \multicolumn{2}{c}{ Sebelum } & \multicolumn{2}{c}{ Setelah } \\
\cline { 2 - 5 } & $\mathrm{F}$ & $\%$ & $\mathrm{f}$ & $\%$ \\
\hline Rendah & 24 & 80 & 1 & 3,3 \\
\hline Sedang & 6 & 20 & 23 & 76,7 \\
\hline Tinggi & 0 & 0 & 6 & 20 \\
\hline
\end{tabular}

Tabel 1 menjelaskan bahwa sebelum diberikan edukasi dan pelatihan pertolongan pertama sebagian besar peserta memiliki pengetahuan pada kategori rendah yaitu $80 \%$ dan kategori sedang yaitu $20 \%$. Sedangkan setelah diberikan edukasi dan pelatihan pertolongan pertama diperoleh pengetahuan penolong pertama kategori baik yaitu $20 \%$, kategori sedang yaitu $76,7 \%$ dan kategori rendah yaitu 3,3\%.

Faktor pendukung kegiatan pengabdian kepada masyarakat adalah adanya dukungan dari pemerintah Desa Lemukutan, masyarakat yang aktif dalam kegiatan pengabdian kepada masyarakat, kegiatan edukasi dan pelatihan yang diikuti peserta sampai selesai. Sedangkan faktor pengahambat dalam kegiatan pengabdian kepada masyarakat berupa kesulitan mengumpulkan banyak peserta karena akibat Pandemi Covid-19 serta adanya kesibukan masyrakat yang bekerja disiang hari. 
Kegiatan pengabdian kepada masyarakat di Desa Lemukutan telah terdokumentasi dengan baik. Berikut gambar pelaksanaan kegiatan pengabdian kepada masyarakat di Desa Lemukutan.
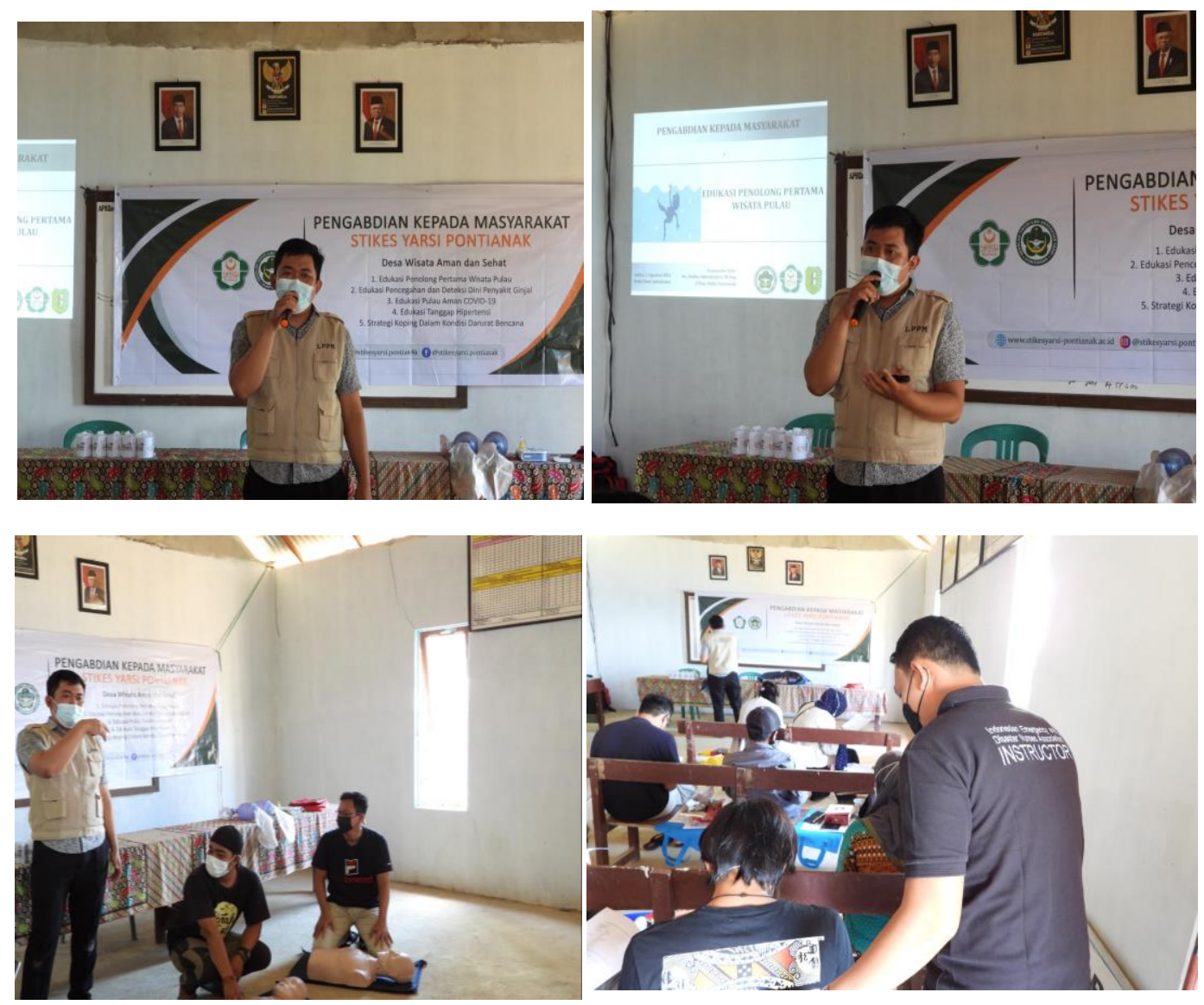

Gambar 2. Kegiatan Pengabdian Kepada Masyarakat di Desa Lemukutan

\section{KESIMPULAN}

Berdasarkan hasil pengabdian kepada masyarakat terdapat peningkatan pengetahuan masyarakat tentang pertolongan pertama.

\section{DAFTAR PUSTAKA}

Bakken, J. P. (2017). Mnemonic Strategies: Helping Students with Intellectual and Developmental Disabilities Remember Important Information. Global Journal of Intellectual \& Developmental Disabilities, 2(3). doi:10.19080/gjidd.2017.02.555587

Benjamin, E. J., Virani, S. S., Callaway, C. W., Chamberlain, A. M., Chang, A. R., Cheng, S., . . . Muntner, P. (2018). Heart disease and stroke statistics - 2018 update: A report from the American Heart Association (Vol. 137).

Budi, S. (2020). Tanggung Jawab Pemerintah Daerah Dalam Penyelenggaraan Kedaruratan Pra-Hospital Melalui Public Safety Center (PSC) 119 Untuk Peningkatan Layanan Kesehatan di Indonesia. Aktualita, 3(1), 547-564. 
Goto, Y., Funada, A., \& Goto, Y. (2018). Relationship between emergency medical services response time and bystander intervention in patients with out-of-hospital cardiac arrest. Journal of the American Heart Association, 7(9), 1-19. doi:10.1161/JAHA.117.007568

Holmén, J., Herlitz, J., Ricksten, S. E., Strömsöe, A., Hagberg, E., Axelsson, C., \& Rawshani, A. (2020). Shortening ambulance response time increases survival in out-of-hospital cardiac arrest. Journal of the American Heart Association, 9(21). doi:10.1161/JAHA.120.017048

IHA. (2015). Pedoman Tatalaksana Sindrom Koroner Akut Edisi Ketiga.

Kleinman, M. E., Brennan, E. E., Goldberger, Z. D., Swor, R. A., Terry, M., Bobrow, B. J., . . . Rea, T. (2015). Part 5: Adult basic life support and cardiopulmonary resuscitation quality: 2015 American Heart Association guidelines update for cardiopulmonary resuscitation and emergency cardiovascular care. Circulation, 132(18), S414-S435. doi:10.1161/CIR.0000000000000259

Krammel, M., Lobmeyr, E., Sulzgruber, P., Winnisch, M., Weidenauer, D., Poppe, M., . . . Nuernberger, A. (2020). The impact of a high-quality basic life support police-based first responder system on outcome after out-of-hospital cardiac arrest. PLOS ONE, 15(6), 2-10. doi:10.1371/journal.pone.0233966

Nurulita, D., \& Darnoto, S. (2017). PROSIDING-SEMNAS \&amp; CALL FOR PAPERS ANALISIS SISTEM INFORMASI INOVASI PSC (PUBLIC SAFETY CENTER) 119 DENGAN METODE PIECES DI DINAS KESEHATAN KABUPATEN BOYOLALI. Prosiding - Semnas \& Call for Papers, 6-11.

Purnamasari, R. (2018). Strategi pembelajaran mnemonic untuk meningkatkan memori siswa. Sipatahoenan, 4(2), 125-138. Retrieved from www.journals.mindamas.com/index.php/sipatahoenan 